DigitALCOMMONS @WAYNESTATE -

\section{Michigan Journal of Counseling: Research, Theory and Practice}

Volume 37 | Issue 1

Article 1

$3-1-2010$

\title{
From the Editorial Desk
}

Perry Francis

Eastern Michigan University

Follow this and additional works at: https://digitalcommons.wayne.edu/mijoc

\section{Recommended Citation}

Francis, P. (2010). From the Editorial Desk, Michigan Journal of Counseling, 37(1), i. doi:10.22237/mijoc/1267401600

This From the Editor is brought to you for free and open access by the Open Access Journals at DigitalCommons@WayneState. It has been accepted for inclusion in Michigan Journal of Counseling: Research, Theory and Practice by an authorized editor of DigitalCommons@WayneState. 


\section{From the Editorial Desk}

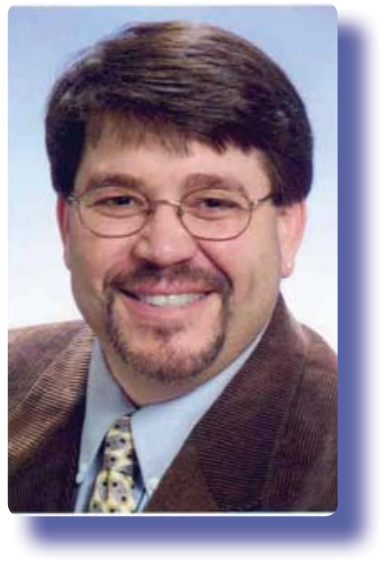

Perry Francis, Ed.D, LPC, NCC

Editor

Dr. Francis is Professor of Counseling at Eastern Michigan

University.

Let me begin my first note to our readers with a word of thanks to our outgoing editor, Dr. Arnie Coven. For the past three years, Dr. Coven has guided our journal and helped to provide valuable information to the profession. In fact, while I may have taken over as editor, the two articles in this issue were shepherded through the editorial process by Dr. Coven. So, truth be told, this is his outgoing issue. Thanks Arnie for your leadership and gentle guidance. Let me also welcome Dr. Irene Ametrano to the editorial review board. Dr. Ametrano is a professor of counseling at Eastern Michigan University and a long time active member in MCA and the profession at large. I also welcome Ms. Laura Hoehn, my editorial assistant, who reads and proofs all submissions to our journal.

The general purpose of a professional journal is to inform and educate its readers, be they students, new professionals, or the seasoned practitioner. Therefore it is the goal of the Michigan Journal of Counseling: Research, Theory and Practice to provide you, the reader, with information that can help educate the student, offer support to the new professional, and provide the seasoned practitioner with usable information that will inform his or her practice with clients. With your help, and the help of the editorial board, we will continue meeting this goal for our membership and other mental health professionals who have access to our journal.

A state counseling journal is an excellent venue for you to offer your proven clinical wisdom, researched and practiced techniques, and original research that informs our profession. Professional counseling is a part of the family of mental health professions (e.g., psychology, social work, \& marriage and family counseling) that should work from the scientist-practitioner model. That is, the mental health professional is a scientist and researcher who apply knowledge and techniques to help facilitate clients to successfully overcome their problems and/or support their normal development. There is a wealth of valuable information stored in the work and research that you do. Now is the time to share that information with your colleagues through this journal. We welcome your articles and will work with you towards the goal of publishing this information. Students and new professionals in our field are also strongly encouraged to submit their original work to the journal. Some of the best information comes from the research that is accomplished by these up and coming professionals.

Our first article for this issue is a validation study on a new psychological instrument used to measure emotional expression through writing. Our second article investigated MCA members' perceptions of spirituality and religion in the therapeutic process. Both articles are useful additional to our knowledge base.

I look forward to the next three years and welcome your input. 